Volume 4 No 2 Maret 2019

p-ISSN : 2460-8750 e-ISSN : 2615-1731

http://dx.doi.org/10.26858/talenta.v4i2.7864

\title{
THE CAREER READINESS AS A TEACHER ON UNIVERSITY STUDENTS BASED ON LOCUS OF CONTROL, SELF ESTEEM, AND PEDAGOGICAL COMPETENCE
}

\author{
RATNA SARI \\ Islamic Education Department, Universitas Muhammadiyah Yogyakarta, Indonesia \\ Email: ratna.sari@umy.ac.id
}

(C2019 -JPT Fakultas Psikologi Universitas Negeri Makassar. Ini adalah artikel dengan akses terbuka dibawah licenci CC BY-NC-4.0 (https://creativecommons.org/licenses/by-nc/4.0/ ).

\begin{abstract}
Abstrack. This research aims to determine the relationship of locus of control, self-esteem, pedagogical competence and career readiness to be a teacher on university students. The population of the research is students of IED at Universitas Muhammadiyah Yogyakarta. The sample is taken using incidental sampling technique. Data collection was conducted by using career readiness scale, locus of control scale, self-esteem scale, and pedagogical competence scale. The data are analyzed using statistical calculation method by using the multiple regressions technique. The results show that; (1) there is no significant relationship between locus of control, self-esteem, pedagogical competence and career readiness to be a teacher, (2) there is a relationship between locus of control and career readiness to be a teacher, (3) there is no relationship between self-esteem and career readiness to be a teacher, (4) there is a correlation between pedagogical competence and career readiness to be a teacher. The total effective contribution of locus of control and pedagogical competence are $14.9 \%$. The effective contribution of locus of control variable is $5.4 \%$ and pedagogical competence variable is $9.5 \%$.
\end{abstract}

Keywords: Career Readiness, Locus of Control, Self Esteem, Pedagogical Competence.

Abstrak. Penelitian ini bertujuan untuk mengetahui hubungan locus of control, harga diri, kompetensi pedagogik dan kesiapan karier untuk menjadi guru pada mahasiswa. Populasi dalam penelitian ini adalah mahasiswa PAI di Universitas Muhammadiyah Yogyakarta. Sampel diambil dengan menggunakan teknik sampling insidental. Pengumpulan data dilakukan dengan menggunakan skala kesiapan karir, skala locus of control, skala harga diri, dan skala kompetensi pedagogik. Data dianalisis menggunakan metode perhitungan statistik dengan menggunakan teknik regresi berganda. Hasilnya menunjukkan bahwa; (1) tidak ada hubungan yang signifikan antara locus of control, harga diri, kompetensi pedagogik dan kesiapan karier untuk menjadi guru, (2) ada hubungan antara locus of control dan kesiapan karier untuk menjadi seorang guru, (3) tidak ada hubungan antara harga diri dan kesiapan karier untuk menjadi seorang guru, (4) ada hubungan antara kompetensi pedagogik dan kesiapan karier untuk menjadi seorang guru. Total kontribusi efektif locus of control dan kompetensi pedagogik adalah 14,9\%. Kontribusi efektif variabel locus of control adalah 5,4\% dan variabel kompetensi pedagogik adalah 9,5\%.

Kata Kunci: Kesiapan Karier, Locus of Control, Harga Diri, Kompetensi Pedagogik

\section{PENDAHULUAN}

The teacher is a strategic component in determining the progress of a nation (Usman, 2010). The main task of the teacher is to teach and educate students in class and outside the classroom (Musfah, 2012). Law number 14 of 2005 concerning 
teachers and lecturers in Indonesia states that teachers are professional educators with the main task of educating, teaching, guiding, directing, training, assessing and evaluating students in early childhood education in formal education, basic education, and secondary education.

Complex teacher roles and assignments will be carried out well when a teacher fulfills the qualifications mentioned in Law number 14 of 2005, namely: academic qualifications, competence, education certificate, physical and spiritual health. A teacher's academic qualifications are obtained undergraduate programs in college or diploma programs. Teachers also need to have competence in accordance with the field of work performed. Based on Law number 14 of 2005 article 10, it is explained that teacher competencies include pedagogical competencies, personality competencies, social competencies, and professional competencies obtained through professional education.

Career readiness as a teacher is formed from two basic components, namely psychological readiness and competencybased preparedness (Baltusite \& Katane, 2014). Phillips and Blustein (2014) stated that several studies found a relationship between career readiness towards psychological variables such as cognitive complexity, problem solving methods and individual self-concepts. Other psychological variables that affect the readiness of an individual career internally include; locus of control and self esteem.

Through interviews with one of the lecturers at the Islamic Education Department (IED), the researcher found that not all IED students were ready to pursue careers as a teacher. The lecturer stated that students have been given teaching theory since semester 1 , but teaching practice activities are; micro teaching and field practice will be obtained by students in semesters 6 and 7, this is the reasons why the teaching skills of students are less honed, therefore, the readiness to become a teacher is less than optimal.

Individuals with a low level of career readiness tend to be less encouraging themselves to learn the knowledge and skills needed for a career as a teacher. This low career readiness level has a negative impact on individual career development in the future.

Koumoundourou et al. (2011) found in his research that external locus of control had an effect on low career readiness. Conversely, the internal locus of control affects high career readiness. The Kaskatayeva (2014) stated that a prospective teacher is important to have high self-esteem in order to be able to 
produce creative ideas, which then have a positive effect on the readiness of a career as a teacher. Hirschi (2011) in his research found that self-esteem was positively related to career readiness. To become a professional teacher requires an ability in the field of education called pedagogic competence (Ismail, 2010). Blyznyuk (2014) in his research found that an important component for a student in choosing a profession as a teacher is the ability to provide meaningful and interesting educational material to establish contact with students. This ability is part of pedagogical competence.

The researcher is interested in examining career readiness for university students to become teachers by paying attention to the fact that there are university students in Islamic education programs who are not ready to become teachers as previously explained. The researcher is interested in reviewing the role of several variables on the readiness of a student career. These variables are the center of control, self-esteem and pedagogic competence.

\section{METODE}

The population in this study were all university students of Islamic education program at Muhammadiyah University of Yogyakarta (Universitas Muhammadiyah Yogyakarta) who had 813 university students in the 2015/2016 academic year. This study uses the incidental sampling techniq. Sampling with incidental techniques involves the most accessible research subjects from the entire population. Based on the Slovin formula, the minimum number of samples is 80 students. This research is conducted by visiting each class and the implementation of the research can be seen in the following table;

Table 1. Research Timeline

\begin{tabular}{|c|c|c|c|c|}
\hline No. & Date & Time & $\begin{array}{c}\text { Class / } \\
\text { Batch / } \\
\text { Semester }\end{array}$ & $\begin{array}{c}\text { Number } \\
\text { of } \\
\text { samples }\end{array}$ \\
\hline 1. & $\begin{array}{l}5 \\
\text { October } \\
2015\end{array}$ & 10.30 & $\begin{array}{l}\text { IED C / } \\
2013 / 5\end{array}$ & 43 \\
\hline 2. & $\begin{array}{l}8 \\
\text { October } \\
2015\end{array}$ & 10.30 & $\begin{array}{l}\text { IED A / } \\
2012 / 7\end{array}$ & 27 \\
\hline 3. & $\begin{array}{l}10 \\
\text { October } \\
2015\end{array}$ & 10.30 & $\begin{array}{l}\text { IED D / } \\
2013 / 5\end{array}$ & 35 \\
\hline \multicolumn{4}{|c|}{ Total of Samples } & 105 \\
\hline
\end{tabular}

Scale is used to uncover psychological symptoms of four variables. The scale used is the scale of career readiness, locus of control scale, selfesteem scale, and pedagogic competence scale. Two scales from the four scales are used, namely the scale of the locus of control and the self-esteem scale. The career readiness scale consists of 21 items based on aspects made by Phillips and Blustein (2014). The planning aspect consists of 6 indicators, namely; interests 
amounted to 2 items, abilities amounted to 2 items, goals amounted to 1 item, observations on several career choices amounted to 1 item, decision making that could affect current activities amounted to 3 items, planning to progress in the desired career direction amounted to 4 items. The exploring aspect consists of 2 indicators, namely; search for information from the media totaling 3 items and information from the closest people as many as 1 item. Each answer item is given a weighted value as shown in the following table:

Table 2. Weight values

\begin{tabular}{lcc}
\hline No. Indicators & \multicolumn{2}{c}{ Statements } \\
\cline { 2 - 3 } & & favorable Unfavorable \\
\hline 1. Very Suitable & 4 & 1 \\
2. Suitable & 3 & 2 \\
3. Unsuitable & 2 & 3 \\
4. Very Unsuitable & 1 & 4 \\
\hline The locus of & control variable \\
measuring instrument & uses a locus of \\
control scale adapted from the scale of the \\
IPC-Locus of Control by Levenson in \\
Azwar (2013) which consists of 24 items. \\
The scale of the IPC-Locus of Control \\
consists of 3 aspects, namely: internal \\
aspects totaling 8 items, others powerful \\
aspects totaling 8 items, and chance aspects \\
consist of 8 items. All items are favorable \\
or unfavorable statements. The next number \\
of scores is used to categorize the scores of \\
subjects with non-nominal categorization \\
techniques. The purpose of categorization is \\
to place subjects into diagnosis groups
\end{tabular}

(Azwar, 2013), namely; internal locus of control, external locus of control, and not classified.

The self-esteem scale consists of 10 items that are used to measure self-esteem. The self-esteem scale is a use scale adapted from the Self Esteem Scale by Rosenberg (Azwar 2013). This scale consists of 4 aspects, namely; overall self-appraisal amounted to 4 items, assessment of individual self-confidence because of they could appear either at work or in school amounted to 2 items, feeling liked by the people around him amounted to 2 items, assessment of a job or achievement produced by individuals amounted 2 items.

The variable pedagogic competence is measured by the scale of pedagogic competence which consists of 21 items with aspects based on the 2006 BSNP totaling 7 aspects. Aspects of understanding insight or educational foundation are two items. The aspect of understanding about students is item. The development aspect of the curriculum / syllabus is 3 items. The learning design aspect is two items. The aspect of implementing learning that is educational and dialogic is 5 items. The evaluation aspect of learning outcomes is 3 items. The development aspect of students to actualize various potentials is 4 items. 
This study uses multiple regression analysis with the stepwise method. The stepwise method is to enter predictors in stages based on a significant $\mathrm{F}$ value (significance $\mathrm{F}$ below 0.05). After the predictor is entered then it is excluded. The insertion process is combined by eliminating non-significant predictors (significance above 0.01). The stepwise method is used because this can know directly the variable $\mathrm{X}$ that is not significant or does not have an effective contribution to variable $\mathrm{Y}$. The data processing in this study entirely uses the SPSS 20.0 for windows computer program.

\section{A. RESULT AND DISCUSSION}

The results of the hypothesis test analysis obtained are as follows;

Table 3. Hypothesis testing

\begin{tabular}{llrrrr}
\hline & & $\begin{array}{c}\text { Career } \\
\text { readiness }\end{array}$ & $\begin{array}{c}\text { Locus of } \\
\text { control }\end{array}$ & $\begin{array}{c}\text { Self- } \\
\text { esteem }\end{array}$ & $\begin{array}{c}\text { Pedagogic } \\
\text { competence }\end{array}$ \\
\hline Pearson & Career readiness & 1,000 &, 272 &, 283 &, 308 \\
Correlation & Locus of control &, 272 & 1,000 &, 194 &, 129 \\
& Self-esteem &, 283 &, 194 & 1,000 &, 580 \\
& Pedagogic competence &, 308 &, 129 &, 580 & 1,000 \\
Sig. $(1-$ & Career readiness &, &, 003 &, 002 &, 001 \\
tailed $)$ & Locus of control &, 003 &. &, 024 &, 095 \\
& Self-esteem &, 002 &, 024 &. &, 000 \\
& Pedagogic competence &, 001 &, 095 &, 000 &. \\
$\mathrm{~N}$ & Career readiness & 105 & 105 & 105 & 105 \\
& Locus of control & 105 & 105 & 105 & 105 \\
& Self-esteem & 105 & 105 & 105 & 105 \\
& Pedagogic competence & 105 & 105 & 105 & 105 \\
\hline
\end{tabular}

From table 3 it can be seen that the relationship between the career readiness variable and the locus of control is 0.272 , which means that this shows a positive relationship. The relationship between selfesteem and career readiness is 0.283 , which means there is a positive relationship. The higher the self-esteem, the higher the career readiness. The relationship between pedagogic competence and career readiness is 0.308 , which means it has a positive relationship, which means that the higher the pedagogical competency, the higher the level of career readiness.

Table 4. Input and output variable

\begin{tabular}{|c|c|c|c|}
\hline Model & Variables Entered & $\begin{array}{l}\text { Variables } \\
\text { Removed }\end{array}$ & Method \\
\hline 1 & $\begin{array}{l}\text { Pedagogic } \\
\text { competence }\end{array}$ & & $\begin{array}{l}\text { Stepwise (Criteria: Probability-of-F-to-enter }<=, 050, \\
\text { Probability-of-F-to-remove }>=, 100) .\end{array}$ \\
\hline 2 & Locus of control & & $\begin{array}{l}\text { Stepwise (Criteria: Probability-of- } F \text {-to-enter }<=, 050, \\
\text { Probability-of-F-to-remove }>=, 100 \text { ). }\end{array}$ \\
\hline
\end{tabular}


The table above shows that the variables included are pedagogical and locus of control competencies. Pedagogic competence enters first then follows the locus of control. This means that the pedagogical competency variable has the highest partial correlation followed by the locus of control variable. Self-esteem variable is not included because this does not bring a significant increase in effective contributions.

\section{The relationship between the locus of} control, self-esteem and pedagogical competence towards career readiness as a teacher for university students

The results of the analysis obtained the value of $F=8.963$, the value of $R=$ 0.387 and the value of $p=0,000(p<0.05)$ in the variable pedagogic competence and locus of control. This shows that there is a significant correlation between the locus of control and pedagogic competence together towards the readiness of career students as teachers. Self-esteem variable is a variable issued, which means that this variable does not make an effective contribution to the career readiness variable.

Overall, the effective contribution of the central control variable and pedagogical competence together is $14.9 \%$. Effective contributions to each variable are; the locus of control is $5.4 \%$ and pedagogical competence is $9.5 \%$. This shows that pedagogical competence provides the greatest contribution to improve career readiness, followed by the locus of control.

Janawi (2012) states that teacher competence is considered by various groups as a description of a professional or unprofessional teacher. The lecturing process at universities prepares students to have pedagogical competence so that students have readiness in a career as a teacher. Students who understand the educational sciences both in theory and practice would have a high level of pedagogical competence so they are ready to have a career as teachers.

Super in his career development theory states that the internal locus of control plays an important role in the success of career planning, career exploration, and efforts to get information and efforts to master certain career-required skills (Mathis \& Roessler, 2010; Savickas, 2002). Students who have an internal locus of control would seriously and actively study educational sciences, and find out information about careers that are chosen consciously or without coercion to increase their capacity as teachers, therefore, students feel ready to have a career as a teacher.

Baumiester (2009) found that high self-esteem can increase self-confidence, 
make individuals consistent despite failure, and increase the desire to seek new challenges. These things have an impact on increasing individual performance. Furthermore, low self-esteem impacts on low performance. University students with high levels of self-esteem are able to adapt to the surrounding environment even in situations of stress, and have a clear concept of careers that will be pursued which then makes students have a career readiness as high teachers. The majority of students in Islamic education program has a moderate level of self-esteem so that it directly influences the ability of students to adapt to the environment which results in students not developing their career choices. The low adaptability of students in the campus environment is evident from the existence of some students who only attend lectures without participating in other activities that can support the readiness of career students such as following campus organizations or educational seminars. As Patton (2004) states that individuals with high self-esteem have a better provision in managing the adaptation process in developing their career choices. Thus, students should be able to adapt well during the lecturing process and participate in activities other than lectures in order to develop student skills so that students have the readiness to work as teachers.

\section{The relationship between the locus of control and career readiness as a teacher for university students}

Partial analysis results that the locus of control variable has a correlation with the career readiness variable. The locus of control variable explains the career readiness variable of $\mathrm{t}=2.561$ and the value of $\mathrm{p}=0.012(\mathrm{p}<0.05)$.

Individuals with internal locus of control tend to feel responsible for their failures and success (Savci \& Ersoy-Kart, 2011). Based on the theory, it is clear that students who have an internal locus of control feel responsible for the future of their careers and strive to obtain information and skills for future career success. Therefore, students who have a high internal locus of control have high career readiness as a teacher.

There are $40.95 \%$ of students who have an internal locus of control. Students with an external locus of control are $52.38 \%$. Students who are not included in the categorization of internal locus of control and external locus of control are categorized as not classified, which is $6.67 \%$. Students who have an internal locus of control will seriously and actively study educational sciences, find out information about careers that are chosen consciously or without coercion to increase their capacity 
163 I Jurnal Psikologi Talenta Vol 4 No. 2

as teachers, so students feel ready to have a career as a teacher.

\section{The relationship between self-esteem} and career readiness as a teacher for university students

A self-esteem variable is exluded. This variable is not included because adding it does not bring about a significant increase in effective contribution. The level of individual self-esteem can affect various aspects of life; such as work, learning achievement, and social relations (Duru \& Balkis, 2014). Individuals with low levels of self-esteem have low motivation as argued by Guindon (2009) that the selfesteem influences individual motivation. In preparing for a career as a teacher, high motivation is needed. The high motivation is related to the high level of self-esteem. Students with a high level of self-esteem have high motivation and are able to adapt to the surrounding environment even in a stressful situation and have a clear concept of a career that is taken so that students have a high career readiness as a teacher.

$11.43 \%$ of students have a low level of self-esteem. The level of self-esteem that is at the moderate level is owned by $75.24 \%$ of students. A total of $13.33 \%$ have a high level of self-esteem. The third minor hypothesis "There is a relationship between self-esteem and career readiness as a teacher for students" is rejected. This means
The Career Readiness as a Teacher on University

that high or low levels of self-esteem have no effect on the level of career readiness.

The researcher observed and obtained several classifications of students in the Islamic Education Department (IED), namely; 1) students enroll in IED for careers to become teachers, 2) students who are forced to apply for IED because they are not accepted in other study programs that are their choices, 3) students who enroll in IED but do not want to have a career as teachers. Students who are classified as number 2 and 3 are the most population in IED. The results of this observation are that the high or low self-esteem of students does not affect the level of career readiness as a teacher, because basically students do not have the desire to have a career as a teacher. Students who have registered for IED should be able to adapt well during the lecture process and participate in activities other than lectures in order to develop the skills of students, therefore, students have the readiness to work as teachers.

In addition, the measurement of self-esteem variables in this study uses a theory that is too broad by using the scale of self esteem by Rosenberg. Fisher in McCullough et al. (1994) explained that measurement required a specific scale to predict attitudes or behavior, because predicting specific attitudes or behaviors using common behavior is difficult to 
resolve. McCullough (1994) added that the more specific scale of self-esteem that can be used in research includes scales related to certain areas such as; self-esteem in the social area or called social self esteem, selfesteem in the academic area or academic self esteem, and self-esteem in the career area called career self-esteem.

\section{The relationship between pedagogical} competencies towards career readiness as a teacher for university students

Partial analysis shows that pedagogical competence variables have a correlation with career readiness variables. The variable pedagogic competence explains the career readiness variable of $\mathrm{t}=$ 3.014 and $p=0.003(p>0.05)$.

Competencies that teachers need to have are very ideal illustrated in Government Regulation No. 19 of 2005 concerning National Education Standards, namely; pedagogic, personal, social, and professional competencies (Musfah, 2011). A prospective teacher or student should have mastered these four competencies to become professional teachers. Janawi (2012) stated the same argument that teacher competence was assessed by various groups as an illustration of whether they were professional or unprofessional teachers. Based on these opinions, a student who masters one of the competencies, namely pedagogical competence, indicates that the student has readiness to become a professional teacher.

The majority of IED students have moderate pedagogical competencies of $82.86 \%$. Students who have a low level of pedagogical competence are $7.62 \%$ and a high level of pedagogic competence is owned by $9.52 \%$ of students. Pedagogical competencies are obtained by students by studying education in the form of theory and practice in educational institutions and doing other activities that support the development of students' ability to teach. This serves as a provision for students' skills in carrying out careers as teachers professionally. Students who understand the science of education both in theory and practice have a high level of pedagogical competence so they are ready to have a career as teachers.

\section{CONCLUSION}

Based on the results of data analysis and discussion, conclusions can be drawn as follows;

1. There is no significant positive relationship between the locus of control, self-esteem, and pedagogic competence with the readiness of a career as a teacher for university students. 
2. There is a relationship between the locus of control and the readiness of a career as a teacher for university students.

3. There is no relationship between selfesteem and career readiness as a teacher for university students.

4. There is a relationship between pedagogical competence and career readiness as a teacher for university students.

5. The effective contribution of the locus of control and pedagogic competence together is $14.9 \%$, and the remaining $85.1 \%$ is determined by other variables, which were not discussed in this study. The effective contribution of the locus control variable is $5.4 \%$ and pedagogical competence is $9.5 \%$.

\section{REFERENCES}

Alfaiz., Daharnis., \& Syahniar. (2013). Kontribusi efikasi diri dan konsep diri terhadap kesiapan arah karier mahasiswa. Jurnal Ilmiah Konseling, 2, 231-238.

Azwar, S. (2013). Penyusunan skala psikologi. Yogyakarta: Pustaka Pelajar.

Baltusite, R., \& Katane, I. (7 - 8 Februari 2014). The structural model of the pedagogy students' readiness for professional activities in the educational environment. Paper dipresentasikan di International Scientific Conference: REEP 2014, Jelgava. Jelgava: Latvia University.
Blyznyuk, T. (2014). Readiness of senior students from the Carpathian terrain to choose teaching profession: pedagogical and psychological aspects. Journal of Vasyl Stefanyk Precarpathian National University, 1, 18-21.

Duru, E., \& Balkis, M. (2014). The roles of academic procrastination tendency on the relationships among self doubt, self esteem, and academic achievement. Education and Science, 39, 274-287.

Francis, A.J.P. (2010). Locus of control. Dalam D. A. Leeming, K. Madden \& S. Marlan (Eds.). Encyclopedia of psychology and religion (pp. 522523). New York: Springer.

Guindon, M.H. (Ed.). (2009). Self-esteem across the lifespan: Issues and interventions. New York: Routledge.

Hirschi, A. (2011). Career-choice readiness in adolescence: Developmental trajectories and individual differences. Journal of Vocational Behavior, 79, 340-348.

Hirschi, A., \& Lage, D. (2007). The relation of secondary student's career choice readiness to a six-phase model of career decision making. Journal of Career Development, 34 (2), 164191.

Ismail, M. I. (2010). Kinerja dan kompetensi guru dalam pembelajaran. Lentera Pendidikan, $13,44-63$.

Janawi. (2012). Kompetensi guru citra guru profesional. Bandung: Penerbit Alfabeta.

Kaskatayeva, B. (7 - 8 Februari 2014). Pedagogical conditions for forming the research competency in future 
teachers of mathematics. Paper dipresentasikan di International Scientific Conference: REEP 2014, Jelgava. Jelgava: Latvia University.

Koumoundourou, G., Tsaousis, I., \& Kounenou, K. (2011). Parental influences on Greek adolescents' career decision-making difficulties: the mediating role of core selfevaluations. Journal of Career Assessment, 19 (2), 165-182.

Mathis, L. M., \& Roessler, R. T. (2010). The relationship between careerrelated knowledge, self esteem, locus of control, gender, and employment outcomes among individuals with learning disabilities. Journal of Applied Rehabilitation Counselling, 41, 311.

McCullough, P. M., Ashbridge, D., \& Pegg, R. (1994). The effect of self esteem, family structure, locus of control, and career goals on adolescent leadership behavior. Adolescence, 29, 605-611.

Melvin, B., Galles, J. A., \& Lenz, J. G. (2012). Assessing career readiness in culturally and ethnically diverse populations. Career Planning and Adult Development Journal, 28, 110-126.

Musfah, J. (2012). Peningkatan kompetensi guru melalui pelatihan dan sumber belajar teori dan praktik. Jakarta: Kencana.

Patton, W., Bartrum, D. A., \& Creed, P. A. (2004). Gender differences for optimism, self-esteem, expectations and goals in predicting career planning and exploration in adolescents. International Journal for Educational and Vocational Guidance, 4 (3), 193-209.
Phillips, S. D., \& Blustein, D. L. (2014). Readiness for career choices: planning, exploring, and deciding. ProQuest Psychology Journals, 43 (1), 1-9.

Richards, G. (2010). Psikologi. (Jamilla. Tran.). Yogyakarta: Penerbit Baca.

Sampson, J. P., Jr., McClain, M. C., Musch, E., \& Reardon, R. C. (2012). Variables affecting readiness to benefit from career interventions. The Career Development Quarterly, 61, 98-109.

Savci, I., \& Ersoy-Kart, M. (2011). Reliability and validity of the career locus of control scale-turkish form. Social Behavior and Personality, 39, 519-520.

Schunk, D. H. (2012). Learning theories. (E. Hamdiah., \& R. Fajar. Trans.). Yogyakarta: Pustaka Pelajar.

Universitas Muhammadiyah Yogyakarta. (2012). Pendidikan agama islam. Diakses Oktober 26, 2015, dari http://goo.gl/kYnooV.

Usman, M. U. (2010). Menjadi guru profesional. Bandung: Remaja Rosdakarya.

Watts, J., Crockcroft, K., \& Duncan, N. (2009). Developmental psychology. Cape Town: UCT Press. Diakses Juni 10, 2015, dari https://goo.gl/34jlUY.

Wade, C., \& Tavris, C. (2012). Psikologi. (B. Widyasinta. Tran.). Jakarta: Erlangga.

Zhuina, D. V. (2014). Diagnostics of career orientation peculiar for the personality of pedagogy students. Life Science Journal, 11 (8), 586589. 